\title{
One Hundred Years of Humor in American Advertising
}

\author{
Fred K. Beard
}

This study addresses a gap in the extensive scholarly literature on advertising humor by exploring advertisers' uses of humor and explanations for its broad appeal as a message tactic throughout the previous century. The study's sources consist mainly of articles published in the important advertising trade journal Printers' Ink, supplemented with more recent articles from contemporary marketing and advertising trade journals. An examination of the evolution of professional thought regarding humor indicates that its use during various periods often represented a response to perceptions of changing societal factors and the consequential need to attract greater attention to advertising, the more frequent use of emotional versus rational appeals, the belief that advertising should entertain, changing perceptions of the role of advertising, and the content of the entertainment media.

Keywords: advertising humor; marketing history; advertising history; advertising message strategy

\footnotetext{
A

round the turn of the last century, most of the seriousminded architects of modern advertising — such as John E. Powers, Albert Lasker, John E. Kennedy, Claude Hopkins, and Ernest E. Calkins-held the use of humor in low favor. Outrageous claims, limericks, slogans combined with "gag cartoons" (Rowsome 1970), racial and ethnic caricatures (Laird 1998), and a "flippant style of copy" (Presbrey 1929) are examples of the shallow humor that can be found in the newspaper and trade-card advertising of the mid- to late1800 s. Most of the progressive members of the emerging discipline, however, preferred to follow the advice of George P. Rowell: "Be serious and dignified, but active and lively. Leave wit, however good it may be, entirely aside" (1888, cited in Presbrey 1929, 276).

Yet the prevalent use and broad popularity of advertising humor among advertisers and audiences confirms its contemporary appeal. Estimates of the use of humor in U.S. television advertising range from 11 percent to 24 percent (Alden, Hoyer, and Lee 1993; Weinberger and Spotts 1989; Speck 1991) to as high as 50 percent (Burnett, Fisk, and Lunsford
}

1987; Speck 1987). Researchers report similar or higher usage in other countries (Alden, Hoyer, and Lee 1993; Toncar 2001; Weinberger and Spotts 1989) and other media (McCullough 1992; Weinberger and Campbell 1991). As Roman and Maas (1976, 25) note, "Everyone likes funny commercials. Creative people like creating them. Advertisers are pleased to be running them. The consumer enjoys them."

Although both academic and industry researchers have studied extensively the characteristics and effects of advertising humor, authoritative explanations for its acceptance among advertisers at various points in time are absent from either the scholarly or trade literatures. This article presents the first attempt to explore the evolution of professional thought regarding the use of humor in advertising for mainly branded, consumer goods from the perspective of the individuals directly responsible for its use. It seeks, in other words, explanations for how modern advertising has arrived at the present state of affairs - visibly dominated by successful (and often unsuccessful) attempts to amuse in the name of persuasion.

The purposes of this study, therefore, are to (1) broadly reveal how humor in advertising has been put to use; (2) provide some sense of past successes and failures; (3) reveal, perhaps, some principles applicable to the future; and (4) satisfy some of the natural curiosity most marketing and advertising practitioners and scholars likely have about their predecessors. As Startt and Sloan (1989) note, "Principles and problems, potential and pitfall can all be underscored by such knowledge" (p. 18). The paragraphs that follow describe the study's method, topical focus, and organization.

Three sets of secondary sources were used in the immersion stage of the study, which consisted of reviewing the sources to aid in topic familiarization, focus, and category development (Smith 1989): (1) advertising histories (Fox

\footnotetext{
The author thanks Anthony Sheung, Taryn Maxwell, and Thomas Beard for their assistance with gathering the data for this study, as well as the Journal of Macromarketing editors and anonymous reviewers for their helpful suggestions.
}

Journal of Macromarketing, Vol. 25 No. 1, June 2005 54-65 DOI: $10.1177 / 0276146705274965$

(C) 2005 Sage Publications 
1984; Laird 1998; Marchand 1985; Meyers 1984; Pope 1983; Presbrey 1929; Rowsome 1970; Schudson 1984; Sivulka 1998); (2) the four existing reviews of the scholarly literature on advertising humor (Beard 2004; Fugate 1998; Sternthal and Craig 1973; Weinberger and Gulas 1992); and (3) the sole survey of advertising agency practitioners' opinions regarding the use of humor (Madden and Weinberger 1984). The histories were also used to provide insight into cultural, professional, economic, and media-related contexts. As Berg $(2001,212)$ notes, "One cannot fully evaluate or appreciate advances made in knowledge, policy, science, or technology without some understanding of the circumstances within which these developments occurred."

Primary sources were obtained from works published chiefly in the trade journal Printers' Ink, referred to as the Little Schoolmaster by founder George Rowell and its devoted readers. The journal was published continuously from 1888 to 1972, although from 1967 to 1972 it was titled Marketing Communications. It was originally intended "for the use, information and entertainment of publishers, printers and general advertisers" (Announcement 1888, 16). Many articles published in Printers' Ink were written by newspapermen, marketing and sales executives, and advertising practitioners, although the staff, including Rowell, also contributed commentary. During the first half of the twentieth century, Printers' Ink was the most widely read advertising trade journal among both agency practitioners and advertisers alike (Laird 1998).

Two hundred and sixty-eight volumes and approximately 3,400 issues of Printers' Ink were published between 1900 and 1972; an index was never published. Because of the volume of records in the database, the author and three trained assistants examined one issue from each volume for articles about humor and advertising message strategy and tactics. The issues were chosen randomly - that is, a random number between one and thirteen was generated for each volume, matching the number of issues - mainly to avoid arbitrary selection.

Tentative categories of analysis were developed inductively at this stage, derived from the theoretical and historical background and purpose of the research. These categories, which emerged early during immersion and in the reading of the materials, include the following: (1) professional beliefs regarding the appropriate tone of advertising (e.g., "dignified" vs. "flippant"), (2) beliefs regarding the nature of the sell (e.g., "hard" vs. "soft"), (3) advertisers' concerns about achieving professional status for themselves and their discipline, (4) concerns about attracting attention to advertising, and (5) the prevalent belief that humor distracts consumers from the sales message.

The author reexamined all the issues inspected by one of the assistants, to aid in category refinement, and worked closely with the others, answering questions and confirming and disconfirming the utility of likely sources. The inductive categories were then applied in the analysis of the records (i.e., articles) in a deductive fashion, using definitions and examples of each category. However, new categories were also allowed to emerge from the closer readings of the articles. Examples of these categories include the following: (1) the influence of the entertainment media, (2) changing perceptions of the audience to which advertising was delivered, and (3) the use of tactical humor with other strategic message approaches. Professional thought for the 1970s through present day was then identified by the author using a literature search, restricted to advertising trade journals, with the goal of producing contemporary records as equivalent as possible to those found in the Little Schoolmaster. The same set of categories and analytical procedures was applied to the contemporary sources.

The qualitative approach used in this study does not provide for the objective assessment of reliability that quantitative content analysis does; the debate among historians over qualitative versus quantitative methods has been long and occasionally acrimonious (Nord 1989). The approach, however, does account for midtwentieth-century objections against superficial analyses resulting from sometimes overly simplistic efforts to quantify data (Mayring 2000). It also has the advantage of being consistent with the methods of traditional, humanistic historical research. In other words, it is "a form of empirical inquiry that uses theoretical constructs to attempt to make true statements about the past" (Nord 1989, 292).

The findings of the study are presented chronologically, detailing contextual background and supporting data for each of five periods. Differing beliefs regarding some issues often appear during the same periods, and the findings reveal often subtle changes in terms of professional thought in general and humor in particular.

\section{"REASON-WHY" AND THE DIGNIFIED SELL: 1900s-1910s}

Much advertising at the turn of the past century was based on providing information, with prominent copywriters such as John E. Powers viewing it as news. "Powers was, perhaps, the first advertising man with a 'nose for news.' He was the first to realize that the everyday happenings of a big store were news, and news that could be made interesting and attractive" (Department store advertising 1902, 8). Industry lore credits John E. Kennedy in 1905 with the more persuasive, hard-sell "salesmanship-in-print" approach (Presbrey 1929; Rowsome 1970), which provided a basis for the influential "reason-why." Neither approach during this period (referred to as "tell vs. sell") relied much on humor. Both evolved as advertising agencies assumed control over the creation of the advertising message and represented virtuous rejections of the showy, aggressive "humbug" style used by many patent-medicine purveyors in the mideighteenth to 
late-eighteenth century (Laird 1998). Hopkins provided insight into the reason-why advocate's opinions regarding humor: "Appeal for money in a lightsome way and you will never get it. People do not buy from clowns" (Hopkins, cited in Rowsome 1970, 138).

The influential, image-oriented, "atmospheric" style of copywriter and agency founder Theodore F. MacManusfeaturing stylishly elaborate layouts and emotional appealswas a direct contradiction of the reason-why and its mainly rational appeals. MacManus's soft-sell approach was well established by 1910 , following advertiser acceptance that there was some necessity "for appealing to the emotions in certain fields of publicity" (Editorial 1903, 34). Yet it too eschewed the use of humor and sought to engage consumers with elitist impressions of "effortless quality and class" (Fox 1984).

Placed in such a context of professional thought, it seems clear why the majority of writers during this period expressed negative opinions toward humor. One frequent criticism was that humor was in poor taste and could easily become offensive and vulgar. Such criticisms were often expressed as warnings against "flippancy" (i.e., impertinence). A second, and related, pervasive belief was that humor is undignified. As one advertiser cautioned, "Don't sacrifice dignity to misapply humor in copy. . . . Coarse jokes and ribald jests and vulgar slang in advertisements are not likely to cause buyers to open their purses" (Editorial 1903, 34). Another advertiser similarly observed, "It's all right to be a clown if you're connected with a circus" (Grey 1908, 35).

The majority of writers, in the mainstream, suggested that negative attitudes toward humor were associated with negativism toward cleverness and novelty in general. "The search for novelty ranks among the greatest channels of waste, beyond doubt" (Novelty 1904, 23). Most advertisers rejected novelty because they believed it would distract readers from the advertising message. Many advertisers' objections to humor, novelty, and cleverness may also have been motivated by professional embarrassment over the excessively dishonest and tasteless humbug advertising of the previous century, as well as the desire to enhance the professional and social status of advertising and its practitioners (Laird 1998; Marchand 1985; Pollay 1985; Rowsome 1970). The majority's attitudes toward humor are well represented by an institutional ad (see Figure 1) for the Lord \& Thomas agency, published in a 1916 issue of Printers' Ink.

Writings about the use of jingles and other forms of "doggerel verse" acknowledged concerns about the need for novelty and the ever-increasing challenge of attracting attention. Limericks, such as those created by Minnie Maude Hanff for the introduction of Force cereal in 1902 (and later continued by Ernest E. Calkins), were among a small handful of intentionally humorous ads used by mainstream advertisers during this period (Fox 1984). As noted by one advertiser, "Whether they sold goods or not I cannot tell. But they surely performed

\section{Lord\&Thomas Creeds}

\author{
No. 8. Sincerity
}

Humor has no plece in advortiting.
Nor hat pottry. Not any touch of lizhtnets.
Spending money is terious busines. And mott folkt wo regard it.

You are seeking confidence. Deserve jt. You we courting respect. Avoid frivolity. Poopla are not readins ade for amusemant. They wall informetion. And they want it from a man who sotms nincere,

Picture a typical cuntomer. Consider his wante-and his ignorance-renpecting whet you bive to well.

Considar the Importance-to him and to you of what you anis him to do.

Write as though that man wer before pou.

Write ac though your futtre dipendid on that alle. Your futurt doms, when your words go to millions.

Don't pane at ad until you feel that the reador will find it resistleas.

Make your cast inpregnablo.

Make overy word ring with truth.

There is nothing od winning in the world at abuolute timeerity. Nothing is so abhorrent an itx lack.

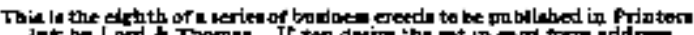

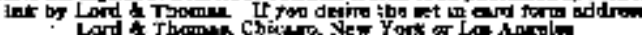

\section{FIGURE 1 THIS 1916 AD FOR THE INFLUENTIAL LORD \& THOMAS AGENCY MAKES ITS POSITION ON HU- MOR IN ADVERTISING ABSOLUTELY CLEAR}

the first function of the advertisement as we understand itthat of attracting attention" (Schwartz 1901, 16). However, it is also important to note that their use soon declinedrepudiated even by Calkins-due to the belief that they failed to sell products (Pope 1983).

Writers also implied that the popular entertainment media influenced their beliefs in favor of a less serious, lighter tone. One writer proposed, "Less dignity and more of the sort of jazz that enlivens the story pages of the magazine might not be amiss in the advertising pages" (Williams 1917, 46). Yet it is clear that even writers in favor of more consumer-focused, novel copy with limited humor never lost sight of the purpose 


\section{H U M O R for Ada, Houes Orgens, elc. Jin- qlen, Jeatn, Take-Offe, Parodien, ete, written to order. Stumtefor Cunventiona, ete. Cartoone and Ciarleaturen made. H. C. GRANT, 305 W. 52 St., N. Y.}

FIGURE 2 A FREELANCE HUMORIST USED THIS 1922 AD IN PRINTERS'INK TO SOLICIT CLIENTS

of advertising — to make a sale. As one writer observed, "It's all right if your ads make people smile-provided also that they make them purchase from you" (Editorial 1902, 10).

\section{EMOTIONAL APPEALS AND ENTERTAINMENT: 1920s-1940s}

Advertising became more personal and consumer focused during the 1920s (Laird 1985; Marchand 1985) as advertisers increasingly viewed human nature as instinctive and nonrational (Curti 1967). George Gallup's seminal researchand the success of "low-brow" publications such as True Story Magazine and the New York Daily News-had confirmed advertisers' suspicions that they were addressing a "tabloid audience" that responded to "unsophisticated, sensationalized, and frivolous entertainment" (Fox 1984). The use of such tactics is consistent with the "visibility school," which proposes "the main task in advertising is to get the public's attention - through humor, bizarre visuals, anything that will grab" (Schudson 1984, 74).

Similar attitudes are reflected in the evolving belief that audience members would respond more to emotional appeals than logical arguments and reasons. This was believed to be especially true for the female audience to which much advertising for branded products during this period was directed. As one advertiser noted, "We have dethroned Old Man 'Reason Why,' and in his stead have crowned Mistress Emotion" (Wallen 1921, 70). By the mid-1930s, the president of the prominent N. W. Ayer \& Son agency was warning advertisers to "remember that very few men are patient enough to untangle a heavy, involved or highly technical description of facts, however interesting the facts themselves might be" (Fry 1935, 71). The use of humor had become sufficiently prevalent by 1922 to justify one freelance humorist's attempt to solicit clients with a classified ad in Printers' Ink (see Figure 2).

However, neither announcement advertising nor the reason-why fell completely from favor during this period (Marchand 1985), nor did their advocates change their minds about humor. Of the articles written about reason-why versus impressionistic advertising, the majority argued in favor of the hard sell and criticized the lack of it. In 1925, the Lord \& Thomas agency ran Figure 3's advertisement in Printers' Ink, cautioning advertisers against the excessive use of "cleverness" and the inclusion of material "extraneous" to their subjects.

Similarly, when the reason-why was adapted for radio in the 1930s by Frank Hummert (Fox 1984), its use was deemed inconsistent with humor. Hummert, who had trained at Lord \& Thomas with Hopkins, would not use humor, cleverness, or novelty, believing they might attract attention but would not sell the product (Fox 1984). Conversely, it is also important to note that Hummert and his colleagues were among the first to hire celebrities, such as Bob Hope and Jack Benny, to endorse products in radio advertising (Meyers 1984). These comedians seamlessly integrated humor with entertainment on the radio, as they would also later do on television.

Writings of this period reveal that advertisers had started using humor in a variety of selling situations, rejecting the reason-why advocates' claim that it was universally applicable (Pope 1983). A writer described the difficulties one advertiser faced in selling his product_-described as "the jigger that stiffens your shoe-upper around the heel, and holds the parts together" (Wilder 1922, 87) — because it was made with man-made material rather than leather. Shoe manufacturers were reluctant to use the product (called a Moussam counter) even though it was better and lasted longer than those made from leather because of a "popular prejudice" in favor of the "all-leather shoe."

This makes it rather difficult at times for the fibre manufacturer, whose customers all admit that his logic is unanswerable, but they can't buy his goods because their retailers demand leather counters. And the retailer also will cheerfully admit the force of the argument, but "all leather" is a talking point too valuable for him to pass up. At any rate, he thinks it is, and the problem is to get him to unthink it. Logic? Forceful, unanswerable, reason-why? Fine! But it happens that he admits all the logic beforehand, and is quite serene about it, which rather deprives a reason-why campaign of some of its force. . . As a result, a semi-humorous vein of copy appeal was developed, with the object of "kidding" the dealer out of his attitude if he could not be pried out of it. (Wilder 1922, 87)

One of the ads from the campaign, which used humorous limericks, is shown in Figure 4.

An article from 1923 described several other instances in which advertisers had adapted humor for trade audiences. "That there is humor in business relations and in advertising arguments appears to be borne out by any number of interesting business paper campaigns of late" (Townsend 1923, 81). Similar to others who described the increasing use of humor, this author defined some emergent principles. For example, he warned of the danger of making fun of the audience. "That's the 'catch' in it-if fun is to be had with anyone, let 


\section{Hold It 2 Weeks}

\author{
Don't publish that "clever" ad \\ just yet - it may be too costly \\ an indulgence
}

\begin{abstract}
A 6000 rude in advertssing is when an ad acems "clever," to holk jt, s,yy two wesk, for atrother reading. Thon you may' Jrop it in the waste lusket.

It is a rule every advertistug asent, every inewspuper atul magasine publisher, every writer slunded have priluted in bold lettets inlet pasted on his will. It wish aive uillinns in hoth dultars and misged sales.
\end{abstract}

Ads that serew clever parely arlt much mercharalise

Ads that are clever never show it. I.ke the sucecssful coojures, they de ther best work witheut the aublerece beirgh consecious of it.

Yet few of us exape the desire, at tumes, w throw of the shackles a bit and "do" a clever pice of capy.

Frs instance, one of the advertisements for nut selves, intended for this geries, was ath in type, ready to go to press, under the heading "Carthinge Nust Be Destroyed."

We wanted to show the power of repetition of a givet thought in advertising. The text dealt with Cato's inevitable watning to the Roman Senate, "Carchage Muat Be Destroyed," as an example of the perwer of stressing a central ides. So we thought that woukd make a fune heading for the ad.

Only our "hold it two werks" rule suved it from broming a published mistikc; beciuse mature cone

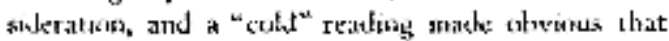

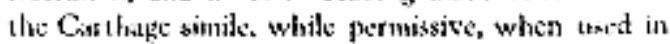

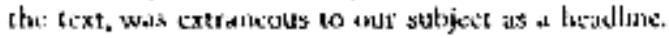

So, the atvertisment wets released with the text unchanged lout with "The Ceritrial ldes in Atvertisinge" as its heading.

The objact of advertising is to sidl gocds by $60 \mathrm{~m}^{\circ}$ vincing the publtic aloos gends are exential in the luwes of prople. Arid that is a seriou kusinesy. Trucks, alengiss, clevertress worth do ic.

You menst moseld public opininn your waky. And thase wezans a conviticing terme, well clusen wernds,

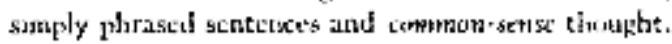

Stukly Arthur Brishane's "TODAY." Mïlitns teid ham, Stesily the style of other gresit editunat writcrs. They swidy sutllionik.

Study successful ondvetersing. Millowy reid it and it stells mullikns. Do that, and you will never run a "devir" as.

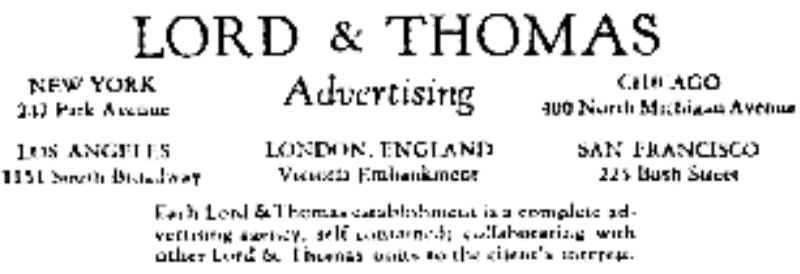

FIGURE 3 THIS 1925 AD IN PRINTERS' INK WARNED ADVERTISERS NOT TO BE TOO CLEVER IN THEIR ADVERTISING

it be the customer, the rival in business, the advertiser himself-but never the person to whom the advertisement is addressed, save under propitious circumstances." He also noted the necessity for humor to be relevant. "The purely irrelevant fun, dragged in by the heels to make a holiday of a headline, is certainly not good business."

Writers during this period also described how they adapted humor for use in consumer advertising. Figures 5's insecticide ad was attributed to the likely failure of a reasonwhy approach. "We found that many of the really sound arguments which are most convincing from a technical and scientific viewpoint fail to carry home in the case of the prospective user, simply because the average housekeeper does not have her mind attuned to that sort of consideration of insects" (O'Connor 1927, 10). The humorous approach was praised for making "it possible to make even roach copy appealing, at least from a reading standpoint" (10).
The description of a consumer campaign from 1930 revealed two more important progressions in professional thought. First, the notion that advertising might usefully entertain without selling at all was mentioned for the first time. Second, as revealed in the following quotation, the writer similarly acknowledged that advertisers might have goals other than directly selling their products:

For a reader doesn't necessarily buy a product because he remembers an advertisement. Nor is he necessarily sold by an advertisement because he remembers what product it advertised. He is sold and he buys because of the second requirement of a good advertisement-that it make an impression, and a favorable one. (Weir 1935, 20)

The ad for coffee shown in Figure 6 accompanied a Printers' Ink article and illustrates both the entertainment 


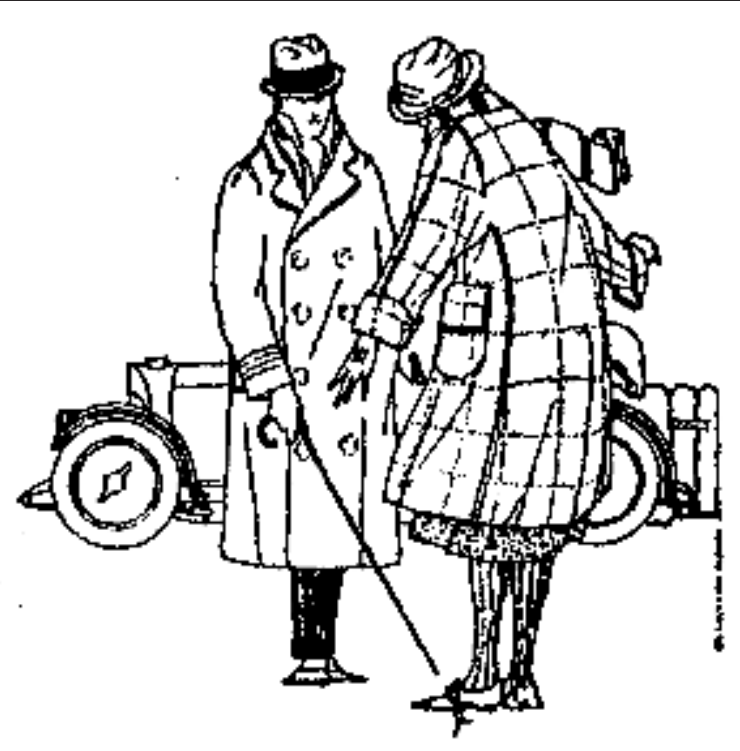

teto une lore the lady wethl.

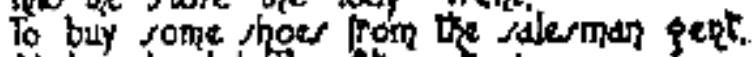
Ah how lowk they it me tool And she plathed twelve doilars On al dillediler thoe.

\section{One day later she had a date. Wilh a John down lown who coutdrit whit, he tcurried dlons os bert she misht, With her left rioe loore ard a wirted rifht,}

\section{to Mourdm Counters in the stoer sie wore. Just cendp from hides and fier lest were sore. At she hove in sobt, John rudely tister.

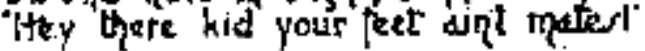

\section{FIGURE 4 AN EARLY 1920s ADVERTISER USED THIS HU- MOROUS LIMERICK AND CARTOON TO OVER- COME THE "LIMITATIONS" OF THE REASON-WHY APPROACH}

orientation and the perceived value of favorable impressions. "The jokes which appear in this campaign are run simply to produce smiles. There is no attempt to have any one of them illustrate or suggest a sales point for Van Dyk coffee. The only selling copy in the advertisements is a phrase which runs under the name slug" (Advertising coffee 1930, 103).

Positive attitudes toward humor and a more entertaining sell in general are associated with two other transitions quite evident during this period. First, some advertisers confirmed the emerging belief that humor appeals to all audiences; for instance, "Almost any person is susceptible to humor. It has an appeal which is undeniably universal" (Townsend 1923, 84-86). As another noted, "George M. Cohan's famous statement, 'Always leave 'em laughing when you say good-bye'

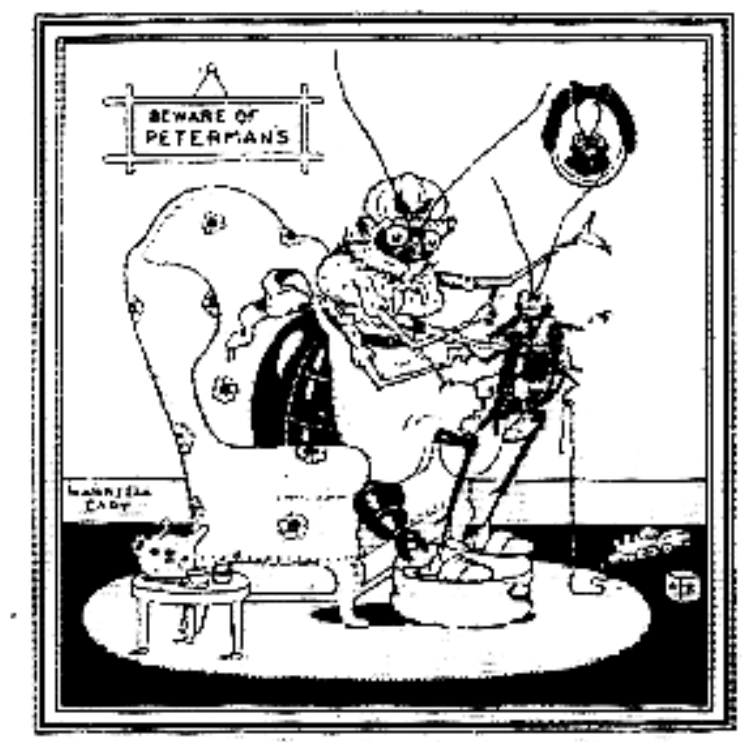

"Beware, ny son, beware!"

"Stay atevey from Pevarman's! It has killedl your wholef fomity

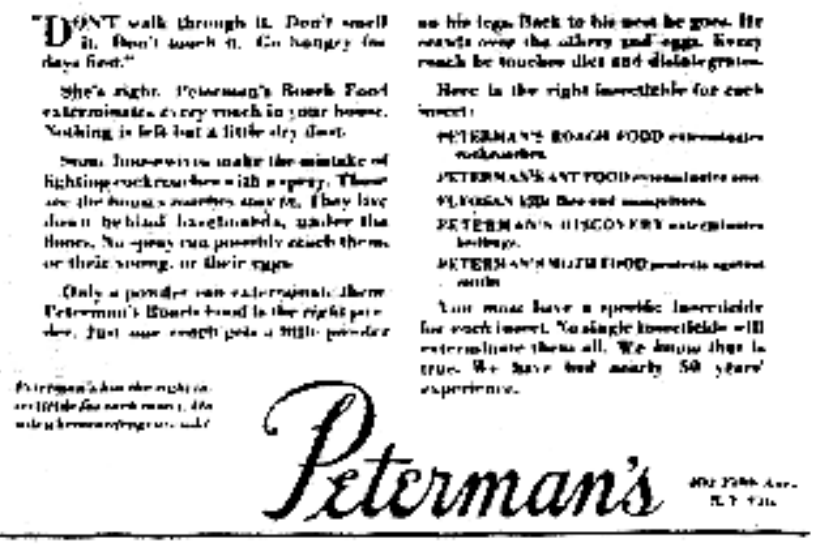

FIGURE 5 PETERMAN'S USED HUMOR TO MAKE ITS ROACH POWDER ADVERTISING MORE APPEALING TO FEMALE HOUSEKEEPERS IN THIS 1927 AD (NOTE THE PHOTO OF DEARLY DEPARTED "PAPA ROACH" ON THE WALL)

has as much meat in it for the advertiser as for the actor" (Advertising coffee 1930, 103). Second, as in the previous period, writers also connected their beliefs in favor of more entertaining and humorous advertising with the influence of the entertainment media. "Adventure, color and romance are taking their place in the best sellers among books and magazines in place of the ultra-realistic stories of a few years ago. This change in the character of words being written by the men who appeal to the great masses, is, in my opinion, being reflected in the advertising pages" (Dickinson 1928, 76). Another related this to the influence of entertainment in print, film, and radio: "the success of the comic strip in newspapers and of comedy acts in the movies, on the stage and over the air 


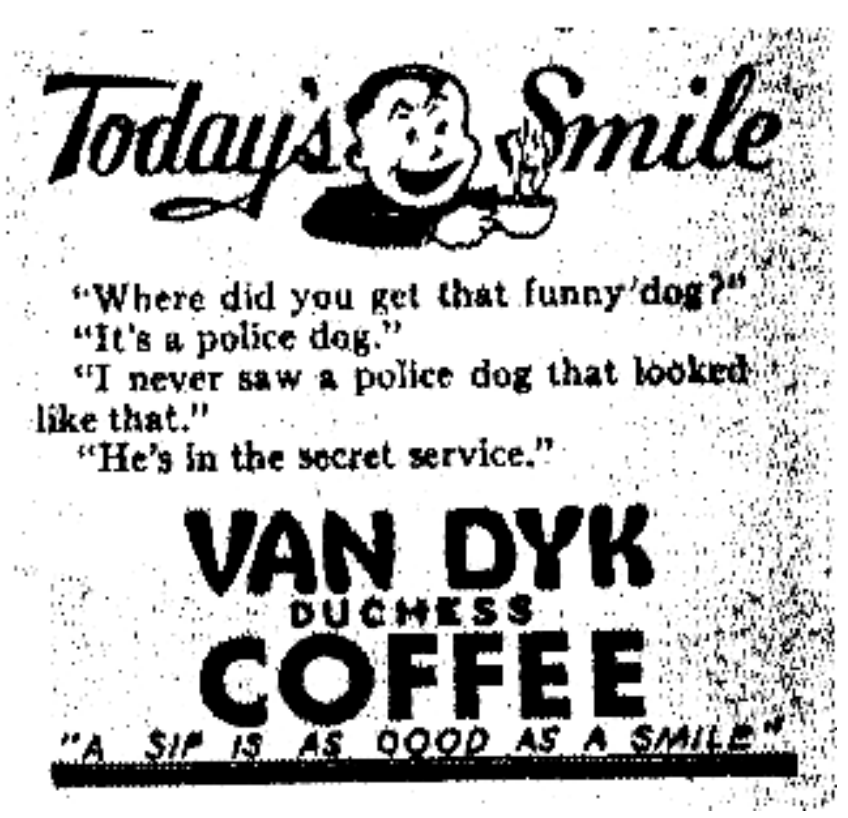

FIGURE 6 THIS 1922 AD SHOWS THAT SOME ADVERTISERS WERE AIMING FOR POSITIVE BRAND IMPRESSIONS BY ENTERTAINING WITH HUMOR

seemed to this company to be convincing proof that nothing succeeds like laughter" (Advertising coffee 1930, 103).

The period is also notable for its use of cartoons and comic strips, not only in consumer advertising but in business-tobusiness and trade advertising as well. Indeed, the classified ad in Figure 7 from a 1927 issue of Printers' Ink indicates that the use of both humor and cartoons had become sufficiently prevalent to merit a freelance cartoonist's advertising of his services.

A decade later, successful work for the Flit-gun by Theodor ("Dr. Seuss") Geisel led to a new client, the Chilton Pen Company Inc. It is interesting to note that Chilton hired Geisel to replace their traditional, nonhumorous advertising ("Formal, serious pictures illuminated formal, serious text") with humorous advertising of the type shown in Figure 8 (It's a real pen name now 1937, 34).

\section{USP AND THE CREATIVE REVOLUTION: THE 1950s-1960s}

The soft-sell impressionistic and hard-sell reason-why schools coexisted in the 1950s and 1960s. Rosser Reeves's contention that a unique selling proposition (USP) was the most important element of an ad had its roots in Kennedy's salesmanship in print; Reeves, in fact, "mentored in the Hopkins 'reason-why' tradition" (Maxwell 1999, 71). At

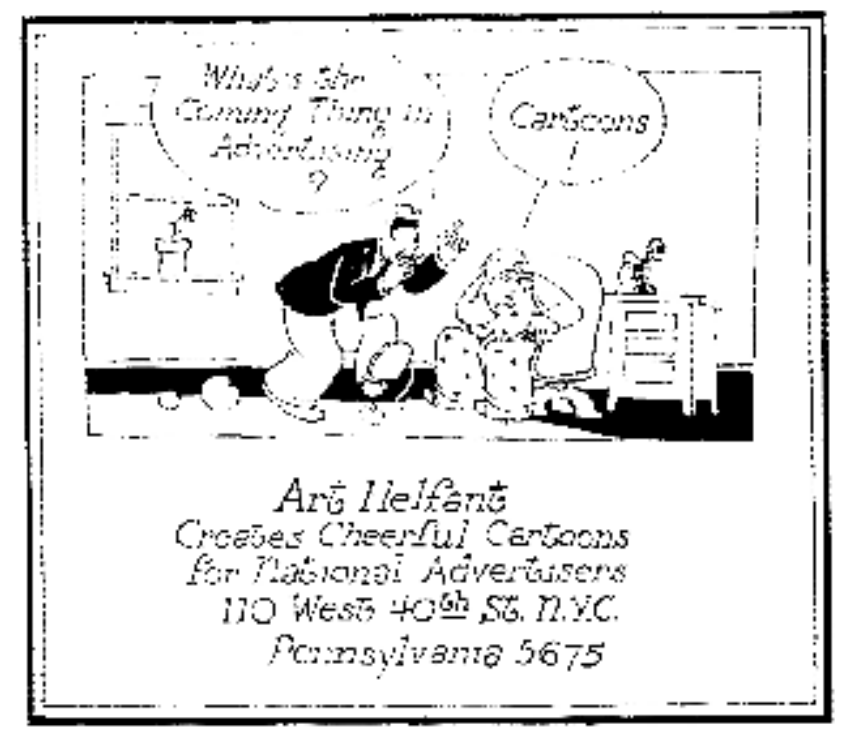

FIGURE 7 A CARTOONIST ADVERTISED HIS SERVICES TO PROSPECTIVE CLIENTS USING THIS 1927 AD IN PRINTERS' INK

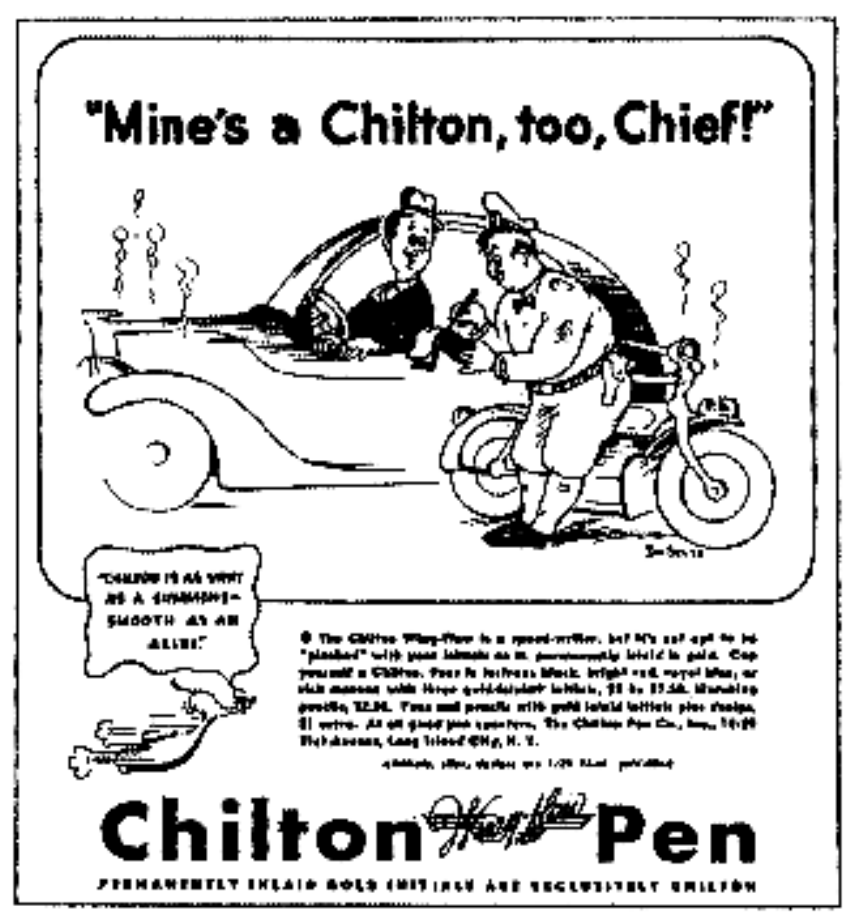

FIGURE 8 THEODOR (“DR. SEUSS”) GEISEL DREW HUMOROUS ADS, SUCH AS THIS ONE, FOR CHILTON PENS, 1937

least one of Reeves prescriptions is strikingly similar to earlier warnings about the distracting nature of novelty: "at all costs, admen should avoid the most dangerous word of all in advertising —originality" (Reeves, cited in Fox 1984, 193). Likewise, David Ogilvy drew on Hopkins's reason-why 
school, but also from the image tradition of MacManus and Young \& Rubicam cofounder Raymond Rubicam (Maxwell 1999). In Ogilvy's (1964) first book, he offered his wellknown admonition to avoid humor because it sells poorly.

Conversely, a creative revolution occurred during this period. The approach of MacManus student and agency founder Leo Burnett (1962) emphasized the "inherent drama" of products and services and often relied on humor and "critters" (Fox 1984). Other Reeves's opponents "wanted advertising to charm, amuse and entertain, along with the sales pitch" (Ad pioneer Reeves, 73, dies 1984, 4). Similarly, William Bernbach's celebrated Volkswagen's advertising of the 1960s_-produced by Bernbach and written and designed by Julian Koenig and Helmut Krone-which often included humor. During this period, Stan Freberg (who had dubbed Reeves "the dean of the Gastro-Intestinal School of Advertising” [Ad pioneer Reeves, 73, dies 1984, 4]) produced humorous ads for Chun King and Contadina; Howard Gossage (who lured Freberg into advertising) wrote "light-hearted copy" (How humor wins reader response 1961, 40) for Rover cars and Eagle shirts; and Mary Wells created humorous ads for Alka-Seltzer and Braniff Airlines (Maxwell 1999).

During this period, especially in the transition to greater use of television, many writers affirmed that the goal of advertising is to be "interesting and entertaining as well as to sell the product" (Local ham jousts national brands on TV 1959, 53). Frequent contributions also reveal that advertisers were continuing the use of tactical humor with reason-why strategies. In an article describing humorous advertising for a business-to-business advertiser, the writer noted, "The ads sell benefits galore" (Keline 1956a). Advertising written and designed by copywriter and humorous book author Ed Zern for the Nash automobile was praised for being "a light approach that mixes humor with selling points that get across all of Nash's important advantages for outdoor sportsmen" (Dever 1951, 53; see Figure 9).

However, as the author of a piece describing a humorous business-to-business campaign noted, humor needs to be relevant: "a fresh approach with the light touch can work wonders for sales, if it can be identified with what you're selling" (Crowell 1957, 28).

In a revealing piece describing "today's rash of tongue-incheek advertising," the writer described how motivation researcher Ernest Dichter linked the use of humor to the positive economic and social tenor of the times and related societal factors.

The old bromide that the average intelligence age of the consumer is 12 has been discarded. Advertisers are secure and they feel they can indulge in some self-kidding. ... And that little old consumer is happy about the possibilities of the future; he is living and laughing it up while letting off steam accumulated over the past 10 years. Thus, the gaiety of the times reflects itself in the advertising of the times. (Keline 1956b, 29-30)

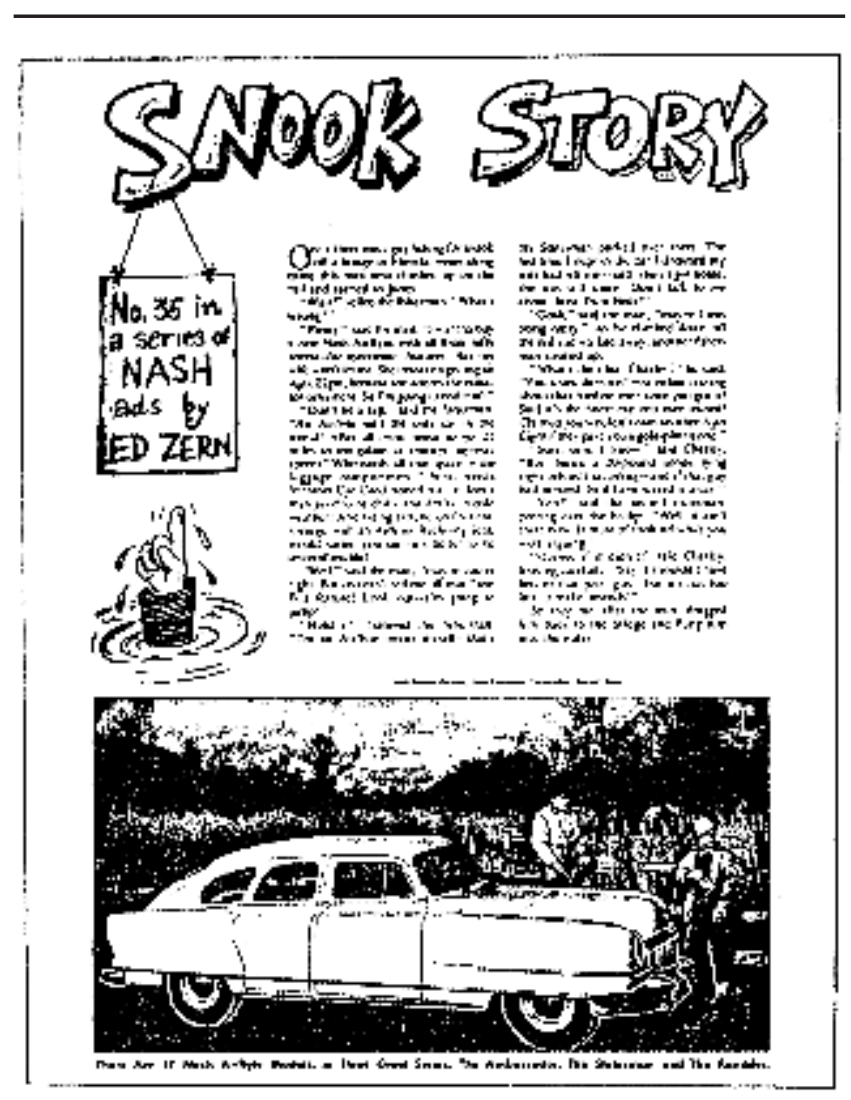

FIGURE 9 HUMOROUS BOOK AUTHOR ED ZERN MIXED HUMOR AND HARD-SELL COPY POINTS IN THIS 1951 AD FOR THE NASH AIRFLYTE

By 1958, on television, both events and writings suggest that advertisers had become sufficiently comfortable with humorous tactics to bend their own rules. For example, one writer described how Bristol Myers "allowed its commercials to be introduced over the CBS television network on Sunday evening prime time by a sardonic man who maligns the sponsor, insults the commercials, and chides the TV audience" (Bristol-Myers' Alfred Hitchcock 1958, 63). The success of Hitchcock's disparaging humor is attributed to its ability "to gain television audience attention for" the commercials, the advertiser's "high degree of sophistication," and a product adaptable to humor (Bristol-Myers' Alfred Hitchcock 1958). However, few, if any, advertising humorists broke more rules during this period than Stan Freberg. Freberg, for example, successfully defied prevailing beliefs with a humorous "pull" radio-and-television campaign for Kaiser aluminum foil that made supermarket managers the butt of the joke.

\section{BACK TO "THE BASICS" AND THE RINEY SOFT SELL: THE 1970s-1980s}

By the early 1970s, the creative revolution was "dead, kaput" (Della Femina 1971), and in the latter half of the 1970s 
and throughout the 1980s, the hard-sell and soft-sell schools coexisted with reason-why in a new form: positioning (Ries and Trout 1981). Some suggest that advertising in the 1970s "harkened back to the 1950s hard-sell style" (Maxwell 1999), influenced, in part, by economic recession and changing perspectives of the audience. "Turned off to today's consumer products is what's happening with many members of the younger set. ... This generation, 'The Basics,' wants to know exactly what is in a product before buying it-more so than any previous generations" (Angelus 1971, 52).

Ogilvy observed that "Today, thank God, we are back in business as salesmen instead of pretentious entertainers. The pendulum is swinging back our way-the Hopkins way" (cited in Maxwell 1999, 84). However, by the time he published his second book in 1985, Ogilvy revealed that he had changed his mind about humor.

Conventional wisdom has always held that people buy products because they believe them to be nutritious, or labor-saving, or good value for money-not because the manufacturer tells jokes on television.... I think this was true in Hopkins' day, and I have reason to believe that it remained true until recently, but the latest wave of factor-analysis reveals that humor can now sell. (103)

There were also signs of another creative revolution in the 1980s, with an increasing reliance on emotional appeals and image advertising (Sivulka 1998). The continuing influence of San Francisco agency founder Howard Luck Gossagewho influenced advertisers everywhere with advertising characterized by witty, wry, and occasionally satirical conversations with consumers-was seen in the work of several agencies, such as the one headed by Hal Riney.

The fewest writings on the topic of humor were found during this period. Those available begin with influential copywriter John Caples ("They laughed when I sat down at the piano. But when I started to play ...”), who began his career as a copywriter in 1925. In a 1975 piece summarizing his "Rules for Advertising," rule eighteen states, "Avoid humor. You can entertain a million people and not sell one of them" (48). Other statements about humor during the period, however, are generally positive and link humor with the belief that it humanizes advertising and possibly the sponsor as well. "Humor needs to come out of human interest-not from vaudeville, not from slapstick, not from sophomoric jokes, not from Madison Ave. 'in' jokes, not from slob characters" (McMahan 1976, 72). Freberg, perhaps the period's most prolific advertising humorist, expressed the notion in the following way: "If a company does a funny spot, it's obviously not taking itself too seriously, right? It must have a good product or else it couldn't afford to kid around. That's the theory" (cited in Bayer 1984, 104).

In the 1980s, Riney's influential soft sell often relied on humor, yet it was generally wry and understated and served primarily to evoke a mood (Winski 1982). Riney's use of humor is linked to his rejection of the hard sell.

We're asking advertising to depend too much on the rational, and much less, or not at all, on the effective element of our business, which is emotion. The rational element is often merely what people use to justify emotional decisions. Knowing when and how to use emotion is the most important part of an advertising person's job. (Riney, cited in Winski 1982, M2)

As in earlier periods, writers acknowledged that the entertainment media influenced their use of humor, as well as other advertising approaches. As one advertiser observed, "Television has changed mass communication more than most people realize. You can look at the guy when he's saying it and see if there is a smile on his lips or a twinkle in his eye. And the visual situation may have a human interest humor all its own that the printed word cannot easily convey" (McMahan 1976, 72). Freberg made the connection more directly: "why not make the sponsor's message as interesting as the show itself?" (cited in Bayer 1984, 106). Still, and despite his belief in the value of humor in advertising, Freberg argued the importance of an appropriate outcome: "a commercial doesn't become an art form to me unless it succeeds at the point of sale or has solved some marketing problem" (cited in Bayer 1984, 110).

\section{AGGRESSIVE HUMOR: THE 1990s-POST-9/11}

Advertisers in the 1990s often expressed concern about advertising's effectiveness and the century-old debate between hard and soft sell continued (Beard forthcoming). The 1990s version of the debate has been described as a basic disagreement between those who believe advertising should directly sell "by giving consumers just the facts" and those in favor of building "an emotional bond between consumers and brands that goes beyond product attributes" (Kuperman, cited in Vagnoni 1997, 20).

In a professional milieu of hard sell, soft sell, and a mix of the two, humor during this period was a frequent topic of discussion. In terms of continuity, many advertisers expressed the belief that humor is appropriate for almost any selling situation and associated it with the soft sell. As a Leo Burnett Co. creative director observed, "Comedy is kind of a universal language. It's a way to get everybody who's watching to sort of engage with your brand" (Akers, cited in Dunlap 2000, 20). Similarly, the belief that humor can attract attention and create a positive mood was frequently mentioned. For instance, "Make people laugh and they like you. If people like you, they pay attention, and attention is what advertisers are paying for" (Valencia 2001, 4). 
One theme that continued during this period was that advertisers should adapt their use of humor to changing societal factors, such as "the mood of the times and the economy in general" (Devaney 2002, 36). The president of the W.B. Doner \& Co. agency expressed this belief in the following way:

Humor is what we took in 1929, during two world wars, Korea, Vietnam and the recession of the 70s. And it's what we will take today. We in the business of selling will employ humor or we'll run the risk of driving consumers to dejection and depression, and away from our products and our stores. (Fried 1991, 26)

This theme became especially apparent following the terrorist attack of September 11, 2001. As Keith Reinhard, chairman of one of the country's largest advertising agencies, observed in an Adweek column, "Given the current mood, now is the time to prove as never before that advertising that sells can also celebrate humanity and mutual affirmation. And that humor, the great sales tool of the ages, does not have to be coarse. It just has to be funny" (Reinhard 2001, 12).

Other writings on advertising humor following 9/11 were consistent with writings from earlier periods regarding inappropriate humor. Moreover, many advertisers prophesied that the attack would especially affect the use of aggressive humor. For example, a creative director for the Cliff Freeman $\&$ Partners agency observed that a commercial in which an ironworker falls off a building and is impaled would not be seen again. "There are certain things you just don't want to go near now" (Silver, cited in Linnett 2002, 6). Similarly, "We've already observed that snide, cynical humor no longer resonates. Poking fun is still fine, but disparagement is not" (Novick 2001, 29). Television commercials for Cliff Freeman \& Partners clients Outpost.com (in which gerbils are fired from a cannon) and Budget Rent A Car Corp. (in which customers fall asleep and ostensibly crash while driving aromatherapy-equipped rental cars) are other examples of the aggressive humor of the present period.

However, many advertisers did not believe the effects of 9/11 on humor would be long term-beliefs that proved prophetic. As summarized by one writer, "According to a number of top creative directors asked to appraise the state of creative advertising at the six-month anniversary of the terror attacks, comedy came back faster than initially imagined" (Vagnoni 2002, 8). Indeed, many Super Bowl XXXVI advertisements, only a few months after 9/11, relied on humor (Devaney 2002), albeit with "softened edges" (Linnett 2002). By Super Bowl XXXVIII, aggressive comedy had possibly exceeded its pre-9/11 levels (Goodman 2004).

Other writings on the topic of humor during this period were also consistent with earlier writings. For instance, observations about the relationship between advertising and entertainment, both before and after 9/11, reveal the continuing belief that advertising should be entertaining. An execu- tive vice president and creative director for Batten, Barton, Durstine, and Osborn New York observed that humor is "a good way to get people to let their guard down and enjoy the story rather than feeling something is being shoved down their throat" (Bruce, cited in Dunlap 2000, 19). Likewise, "If there was ever a time when advertising and entertainment needed to converge, it's now.... With 'their worst nightmare' on their minds, we need to entertain to break through. Ads that entertain are like oxygen: a moment to breathe, a release from the events of the day" (Novick 2001, 29).

As in earlier periods, writers linked the characteristics of advertising humor to those of the entertainment media. One advertiser observed, "Almost by instinct we follow the lead of events and entertainment" (Fried 1991, 26). The aggressive humor of this period was linked to the influence of much earlier Saturday Night Live ad parodies by one advertiser (Valencia 2001). The frequent use of extreme "frat boy" humor in the latter part of the 1990s (Donaton 1999, 36) was attributed to youth-oriented films such as Scary Movie and MTV (Dunlap 2000).

Finally, and quite appropriately, advertisers in the final decade of the twentieth century expressed concerns similar to their predecessors about the effective use of humor and its relationship to the proper role of advertising. "Just to keep people from zapping you is not reason enough to do something that is totally irrelevant to what you're selling" (Freberg, cited in Garfield 1992, 52). Referring to humorous TV commercials for Rice Krispies Treat Bars, the director of the commercials noted, "We didn't do this work just to have fun.... We did it to execute a business objective, which was to appeal to teens and become a relevant brand in their lives" (Tozzi, cited in Dunlap 2000, 20).

\section{SUMMARY AND CONCLUSIONS}

During the first decade or so of the past century, the majority of major U.S. advertisers favored serious, rational advertisements that were delivered to what was believed to be a likewise serious-minded audience. Humor was mainly avoided because it was seen as undignified and in poor taste - a professionally embarrassing reminder of the humbug entertainment and patent-medicine advertising of the previous century. It was also viewed as inconsistent with what was believed to be effective advertising - that which sells products directly. The criticism that "humor doesn't sell" continued throughout the twentieth century.

Early beliefs that humor threatened the dignity of advertisers seem similar to contemporary beliefs that humor contributes little to source credibility (Madden and Weinberger 1984). It also seems likely that "tasteful" humor became acceptable to some advertisers during the first decade or so of the twentieth century as they became progressively more concerned about attracting attention to their advertising. As Laird (1998) noted, competition intensified during this 
period, as productivity increased; regional products became national, branded ones; and print media proliferated. Thus, it seems clear why advertisers began to argue that advertising should be more consumer focused, less dignified, lighter, original, clever, and novel. That humor can attract attention was referenced frequently and consistently by advertisers throughout the twentieth century.

The findings reveal that professional thought in favor of humor evolved along with (1) the more frequent use of emotional appeals of all kinds; (2) changing perspectives of audiences and their characteristics; (3) the recognition that advertising might help achieve marketing objectives other than selling products directly; (4) the rediscovery that advertising should, in certain situations, entertain; (5) changes in the content and tone of the entertainment media; (6) the emergence of the broadcast media, first radio and then television; and (7) the slowly evolving belief that humor and novelty need not necessarily be distracting if they are relevant. Consistent with Gallup's finding that people enjoy cartoons and comics, use of these elements provided a point of entry for the more frequent and occasionally respectable use of humor during the 1930s.

Although humor is often associated with emotional appeals and the soft sell, it is interesting to note that advertisers as early as the late 1920 s were combining tactical humor with rational, reason-why-style selling points. Such a finding is consistent with Madden and Weinberger's (1984) finding that contemporary advertisers believe humor can enhance the registration of simple copy points. This discovery also helps explain another unexpected finding: despite the professional taboo that business-to-business advertisers should avoid humor, among the earliest uses of humor were advertisements targeting trade audiences. The use of humor in in business-to-business advertising was common throughout the past century.

The findings and conclusions of this study are, of course, limited in several ways. Whereas some contextual background provides insight into the use of humor in nineteenthcentury advertising, data collection was limited to the twentieth century. As noted earlier, although qualitative approaches to content analysis are consistent with traditional historical research methods, they lack strong evidence for reliability. This study is also limited by the sources used for the final thirty years of the twentieth century, mainly in that advertisers themselves were generally no longer primary sources. Their beliefs and opinions, although still often in their own words, became filtered by the journalists who interviewed them.

The study is also limited by the absence of a broad, representative sample of advertisements themselves. Future historical research on the use of humor in advertising could usefully attempt to confirm the findings using advertisements, biographies, and autobiographies of advertising practitioners, as well as early and contemporary textbooks. In addition, a content analysis of humorous ads would offer an opportunity to address another limitation of this study: its treatment of advertising humor throughout the previous century as a homogeneous phenomenon. Recent research on humor types would provide a useful approach for examining the types of humor used during different periods, for different types of products, and in the various mass media.

Finally, given that the findings of this historical study indicate that the use of humor in advertising seems to be mainly influenced by prevailing professional thought, it would be insightful to replicate the sole existing survey on the topic among advertising practitioners (Madden and Weinberger 1984). The infrequent reference to scientifically conducted research on the effects of advertising humor in the professional discussion on the topic further suggests the value of comparing professional beliefs regarding its effectiveness with conclusions based on the broad and growing body of scholarly and academic research literature.

\section{REFERENCES}

Ad pioneer Reeves, 73, dies; proponent of hard sell, USP. 1984. Advertising Age 55 (4): 4, 84.

Advertising coffee with a joke a day. 1930. Printers' Ink 152 (11): 103.

Alden, D. L., Wayne Hoyer, and Choi Lee. 1993. Identifying global and culture-specific dimensions of humor in advertising: A multinational analysis. Journal of Marketing 57:64-75.

Angelus, Ted. 1971. New product payout. Marketing Communications 299 (1): 51-52.

Announcement. 1888. Printers' Ink 1 (1): 16.

Bayer, Cary. 1984. A laugh a minute. Madison Avenue 25 (11): 100-10.

Beard, Fred K. 2004. Humor in advertising: A review of the research literature, 1993-2003. Paper presented at the 9th International Conference on Corporate and Marketing Communications (CMC), Coventry, England.

_. forthcoming. Hard-sell killers and soft-sell poets: Modern advertising's enduring message strategy debate. Journalism History.

Berg, Bruce L. 2001. Qualitative research methods for the social sciences. 4th ed. Needham Heights, MA: Allyn \& Bacon.

Bristol-Myers' Alfred Hitchcock: His 'personality' sells what he derides. 1958. Printers' Ink 264 (3): 63-68.

Burnett, Leo. 1962. Sampling the works of Leo Burnett. Printer's Ink 278 (10): 33-38.

Burnett, M., R. Fisk, and D. A. Lunsford. 1987. Humorous appeals in television advertising: A content analysis. In Proceedings of summer educators' conference, edited by S. P. Douglas. Chicago: American Marketing Association.

Caples, John. 1975. 50 things I have learned in 50 years in advertising. Advertising Age 46 (38): 47-48.

Crowell, Peter P. 1957. This campaign is screwy, but . ... Printers' Ink 260 (5): 28-29.

Curti, Merle. 1967. The changing concept of "human nature" in the literature of American advertising. Business History Review 41:335-57.

Della Femina, Jerry. 1971. The death of the creative revolution. Marketing Communications 299 (2): 16.

Department store advertising. 1902. Printers' Ink 38 (10): 8-10.

Devaney, Polly. 2002. Cheerful super bowl ads mask a deeper malaise. Marketing Week, February 28, 36.

Dever, Edward J. 1951. Humor mixed with facts sells general product to special market. Printers' Ink 237 (5): 53-54, 58.

Dickinson, Roy. 1928. An idea plus romance as a copy formula. Printers' Ink 145 (9): 5, 73-76. 
Donaton, Scott. 1999. No laughing matter: "Frat-boy" humor spreads into advertising. Advertising Age 70 (47): 36.

Dunlap, Bill. 2000. Funny business. Shoot 41 (31): 19-21.

Editorial. 1902. Printers' Ink. Reprint from White's Sayings 38 (10): 10. -. 1903. Printers' Ink 45 (11): 34.

Fox, Stephen. 1984. The mirror makers: A history of American advertising and its creators. New York: Vintage Books.

Fried, Herbert. 1991. Humor is our best tool. Advertising Age 62 (15): 26.

Fry, Wilfred W. 1935. Why advertising must have human approach. Printers' Ink 275 (7): 40.

Fugate, D. L. 1998. The advertising of services: What is an appropriate role for humor? The Journal of Services Marketing 12 (6): 453-72.

Garfield, Bob. 1992. Freberg: Humor's no laughing matter. Advertising Age 63 (3): 52.

Goodman, Tim. 2004. Super Bowl ads strain for cheap laughs. San Francisco Chronicle, February 2, A2.

Grey, John S. 1908. The crude in advertising. Printers' Ink 63 (12): 35.

How humor wins reader response. 1961. Printers' Ink 275 (7): 40.

It's a real pen name now. 1937. Printers' Ink 181 (2): 24-26.

Keline, N. 1956a. These business-magazine ads get laughs . . . and still sell. Printers' Ink 255 (5): 24-25.

—. 1956b. Tongue-in-cheek ads—New copy craze. Printers' Ink 254 (3): 28-30.

Laird, Pamela W. 1998. Advertising progress: American business and the rise of consumer marketing. Baltimore: Johns Hopkins University Press.

Linnett, Richard. 2002. Ad creativity feels pressure. Advertising Age 73 (36): 6.

Local ham jousts national brands on TV. 1959. Printers' Ink 267 (4): 53.

Madden, Thomas J., and Marc G. Weinberger. 1984. Humor in advertising: A practitioner view. Journal of Advertising Research 24 (4): 23-30.

Marchand, Roland. 1985. Advertising the American dream: Making way for modernity, 1920-1940. Berkeley: University of California Press.

Maxwell, Ann. 1999. From advertising to marketing. In Advertising and the business of brands, edited by Bruce Bendinger and Jim Avery: Chicago: The Copy Workshop.

Mayring, Philipp. 2000. Qualitative content analysis. Forum: Qualitative Social Research 1 (2). Available at agb.east.asu.edu.

McCullough, L. S. 1992. The use of humor in international print advertising: A content analysis. Working paper, Miami University, Oxford.

McMahan, Harry Wayne. 1976. So funny it ain't funny: Sort of a serious look at humor. Advertising Age 47 (37): 72.

Meyers, William. 1984. The image-makers: Power and persuasion on Madison Avenue. New York: Times Books.

Nord, David P. 1989. The nature of historical research. In Research methods in mass communication, 2nd. ed., edited by Guido H. Stempel III and B. H. Westley, 290-315. Englewood Cliffs, NJ: Prentice-Hall.

Novelty. 1904. Printers' Ink 48 (1): 23-24.

Novick, Steve. 2001. Advertising, pure and simple. Advertising Age 72 (46): 29.

O'Connor, J. T. 1927. Liven up that technical copy with a little humor. Printers'Ink 139 (9): 10-12.

Ogilvy, David. 1964. Confessions of an advertising man. New York: Atheneum.

- 1985. Ogilvy on advertising. New York: Vintage Books.

Pollay, Richard W. 1985. The subsiding sizzle: A descriptive history of print advertising, 1900-1980. Journal of Marketing 49:24-37.

Pope, Daniel. 1983. The making of modern advertising. New York: Basic Books.

Presbrey, Frank. 1929. The history and development of advertising. Garden City, NY: Doubleday.
Reinhard, Keith. 2001. Now is the time. Adweek 42 (41): 12.

Ries, Al, and Jack Trout. 1981. Positioning: The battle for your mind. Rev. ed. New York: McGraw-Hill.

Roman, Ken, and J. Maas. 1976. How to advertise. New York: St. Martin's.

Rowsome, Frank, Jr. 1970. They laughed when I sat down: An informal history of advertising in words and pictures. New York: McGraw-Hill.

Schudson, Michael. 1984. Advertising: The uneasy persuasion. New York: Basic Books.

Schwartz, J. W. 1901. About jingles. Printers' Ink 34 (7): 16.

Sivulka, Juliann. 1998. Soap, sex, and cigarettes. Belmont, CA: Wadsworth.

Smith, MaryAnn Yodelis. 1989. The method of history. In Research methods in mass communication, 2nd. ed., edited by Guido H. Stempel III and B. H. Westley, 316-30. Englewood Cliffs, NJ: Prentice-Hall.

Speck, Paul S. 1987. On humor and humor in advertising. Ph.D. diss., Texas Tech University.

- 1991. The humorous message taxonomy: A framework for the study of humorous ads. In Current issues and research in advertising, vol. 13, edited by James H. Leigh and Claude R. Martin Jr. Ann Arbor: Michigan Business School.

Startt, James D., and W. David Sloan. 1989. Historical methods in mass communication. Hillsdale, NJ: Lawrence Erlbaum.

Sternthal, B., and C. S. Craig. 1973. Humor in advertising. Journal of Marketing 37: 12-18.

Toncar, M. F. 2001. The use of humour in television advertising: Revisiting the US-UK comparison. International Journal of Advertising 20 (4): 521-40.

Townsend, A. L. 1923. How to use humor in advertising to the dealer. Printers' Ink 125 (3): 81-88.

Vagnoni, Anthony. 1997. Creative differences. Advertising Age 68 (46): 1, 20, 28.

2002. Fear of funny abating. Advertising Age 73 (10): 8, 42.

Valencia, Angelo. 2001. Cutting sense of humor. Shoot 42 (37): 4-5.

Wallen, James. 1921. Is old man "reason why" dead? Printers' Ink 117 (7): 69-70.

Weinberger, Marc C., and Leland Campbell. 1991. The use and impact of humor in radio advertising. Journal of Advertising Research 31:44-52.

Weinberger, Marc C., and C. Gulas. 1992. The impact of humor in advertising: A Review. Journal of Advertising 21:35-59.

Weinberger, Marc C., and Harlan E. Spotts. 1989. Humor in U.S. versus U.K. TV advertising. Journal of Advertising 18 (2): 39-44.

Weir, W. J. 1935. Sir veigh, ad-critic. Printers'Ink 170 (9): 19-24.

Wilder, John P. 1922. Fighting a trade bogie with ridicule. Printers' Ink 120 (1): 87-88.

Williams, Frank H. 1917. Copy writers, won't you please liven up? Printers' Ink 107 (9): 45-47.

Winski, Joseph M. 1982. He swims against the tide. Advertising Age 53 (18): M1-M6.

Fred K. Beard (Ph.D., University of Oklahoma) is a professor of advertising and director of research for the Gaylord College of Journalism and Mass Communication, University of Oklahoma. His work has been published in the Journal of Advertising, the Journal of Advertising Research, the Journal of Business Research, the Journal of Business Ethics, and the Journal of Marketing Communication, among others. 